\title{
Dokument
}

\section{Barack Obamas tale til berlinerne}

Jeg er kommet til Berlin, som mange af mine landsmænd er kommet her før. Men i aften taler jeg ikke til jer som præsidentkandidat, jeg taler til jer som borger. Som en stolt borger i De Forenede Stater og som en medborger i verden.

Jeg ved, at jeg ikke ligner de amerikanere, som tidligere har talt $\mathrm{i}$ denne betydningsfulde by. Den rejse, der førte mig hertil, er usædvanlig. Min mor blev født i hjertet af Amerika, men min far voksede op som gedehyrde i Kenya. Hans far min farfar - var kok og tjener for briterne.

Da Den Kolde Krig var på sit højeste, besluttede min far, som mange andre i verdens glemte hjørner, at hans længsel - hans drøm - ikke ville kunne indfris uden den frihed og de muligheder, som Vesten giver løfte om. Han skrev derpå breve til universiteter over hele Amerika i håbet om, at nogen, et eller andet sted, ville høre hans bøn om et bedre liv.

Og dette er grunden til, at jeg står her i aften. Og til at I er her. For også I kender til denne længsel. Af alle byer kender denne by alt til drømmen om frihed. Og som I ved, er grunden til, at vi står her i aften, at mænd og kvinder fra begge vore nationer gik sammen om at arbejde, kæmpe og ofre sig for dette bedre liv.

Sammen har vi et partnerskab, som i sandhed begyndte en sommerdag for 60 år siden, da det første amerikanske fly satte sine landingshjul på cementen i Templehof.

Det var en dag, hvor store dele af dette kontinent stadig lå i ruiner. Af stenbrokkerne i denne by var der endnu ikke blevet opført en mur. Sovjetunionens skygge havde lagt sig over Østeuropa, og i Vesten gjorde Amerika, Storbritannien og Fran-

Barack Obama, Demokraternes kandidat til det forestående præsidentvalg i USA den 4. november, vakte kolossal opmærksomhed, da han talte i Berlin den 24. juli. "Skal vi være ærlige over for hinanden", sagde han, "så ved vi godt, at vi på hver vores side af Atlanten undertiden er gledet fra hinanden". Men Obamas budskab var, at USA og Europa må gå sammen om at forkaste fortidens koldkrigstænkning og samarbejde om at redde planeten fra konflikter og klimatrusler. 
krig status over deres tab og overvejede, hvordan verden kunne genopbygges.

Det var på dette sted, at de to sider mødtes. Den 24. juni 1948 valgte kommunisterne at blokere den vestlige del af byen. De afskar fødevareleverancer $o g$ andre forsyninger til over to millioner tyskere i et forsøg på at slukke frihedens sidste flamme i Berlin.

Vore styrkers størrelse kunne ikke hamle op med Sovjetunionens langt større hær. Og dog ville tilbagetog have ladt Europa åben for kommunismens fremmarch. Hvor forrige krig var afsluttet, kunne en ny verdenskrig meget vel være begyndt. Kun Berlin stod i vejen for dette.

Da var det, at luftbroen begyndte, og historiens mest usædvanlige undsætningsaktion bragte mad og håb til borgerne i denne by.

$\mathrm{Al}$ sandsynlighed talte imod, at aktionen skulle lykkes. Ved vintertide fyldte en massiv tåge himmelen over Berlin, og mange fly blev tvunget til at vende om uden at have afleveret de forsyninger, som der var så desperat brug for. De gader, hvor vi i dag står, var fyldt med sultne familier, som ikke havde noget værn mod kulden.

Men selv i denne dystre stund holdt Berlins borgere liv i håbets flamme. Berlin nægtede at give op. Og en efterårsdag kom hundredtusindvis af berlinere her til Tiergarten og hørte byens borgmester appellere til verden om ikke at lade fri- heden i stikken. "Der er kun en mulighed," sagde han: "At vi står sammen, indtil dette slag er vundet ... Berlins borgere har talt. Vi har gjort vor pligt og vi vil fortsætte med at gøre vor pligt. Borgere i verden: Gør nu jeres pligt ... Borgere i verden se Berlin!"

Borgere i verden - se Berlin!

Se Berlin, hvor tyskere og amerikanere lærte at arbejde sammen i gensidig tillid, mindre end tre år efter at de havde stået over for hinanden på slagmarken.

Se Berlin, hvor et folks beslutsomhed blev mødt med Marshall-planens generøsitet og skabte et tysk mirakel. Hvor en sejr over tyranniet førte til oprettelse af NATO, den stærkeste alliance, der nogensinde er formet for at forsvare vor fælles sikkerhed.

Se Berlin, hvor skudhuller i bygningerne og de dystre sten og søjler ved Brandenburger Tor insisterer på, at vi aldrig glemmer vor fælles menneskehed.

Borgere i verden - se Berlin, hvor en mur blev væltet, et kontinent forenet og historien beviste, at der ikke findes nogen udfordring, der er for stor for en verden, der står sammen som én.

\section{Verden er gensidigt afhængig}

60 år efter luftbroen kaldes der igen på os. Historien har ført os til en ny korsvej, med nye løfter og nye farer. Da I, det tyske folk, rev Muren ned - 
den mur, der skilte $\varnothing_{\text {st }}$ og Vest, frihed og tyranni, frygt og håb - væltede også andre mure verden over.

Fra Kijev til Capetown blev fangelejre lukket og demokratiets døre åbnet. Også markeder åbnedes op, og udbredelse af informationer og teknologi sænkede barriererne for frie initiativer og velstand.

Hvor det 20. århundrede lærte os, at vi deler en fælles skæbne, har det 21. afsløret en verden for os, der er mere gensidigt afhængig end nogensinde tidligere i historien.

Berlinmurens fald bragte nyt håb. Men den samme nære forbundethed har givet anledning til nye farer - farer, som ikke kan inddæmmes bag et lands grænser eller af et oceans afstand.

Terroristerne fra 11. september konspirerede i Hamborg og trænede i Kandahar og Karachi, før de myrdede tusinder af mennesker fra alle dele af kloden på amerikansk jord.

Og i dette øjeblik er biler i Boston og fabrikker ved at smelte iskapperne i Arktis, trænge Atlanterhavets kyster tilbage og udløse tørke i landbrug fra Kansas til Kenya.

Uforsvarligt sikret atomart materiale i det tidligere Sovjetunionen eller hemmeligheder fra en videnskabsmand i Pakistan kan bidrage til at bygge en bombe, der detonerer i Paris. Valmuer i Afghanistan bliver til heroin i Berlin. Fattigdom og vold i Somalia avler morgendagens terror. Folkemordet i Darfur giver os alle skamfuld samvittighed. I vore dages verden løber sådanne nye farlige strømninger hurtigere end vore bestræbelser på at holde dem tilbage. Dette er grunden til, at vi ikke har råd til splittelse. Ingen nation, uanset hvor stor eller magtfuld, kan overvinde sådanne udfordringer på egen hånd.

Ingen af os kan fornægte disse trusler eller flygte fra vort ansvar for at imødegå dem. I fraværet af de sovjetiske kampvogne og den grufulde mur er det ganske vist blevet let at glemme denne sandhed. Og skal vi være ærlige over for hinanden, så ved vi godt, at vi på hver vores side af Atlanten undertiden er gledet fra hinanden og har glemt den skæbne, vi deler.

\section{Det globale medborgerskabs byrder}

I Europa er det blevet et alt for udbredt synspunkt, at Amerika er en del af verdens dårligdomme snarere end en kraft, der kan hjæelpe til at udbedre dem. I Amerika er der røster, som nedgør og benægter Europas meget væsentlige rolle for vor sikkerhed og fremtid. Begge synspunkter rammer forbi sandheden. For sandheden er, at europæerne i dag har påtaget sig at bære nye byrder og større ansvar i verdens kritiske zoner. Og ganske som de amerikanske baser, der blev opført i sidste århundrede, stadig bidrager til at forsvare sikkerheden på dette kontinent, yder vort land stadig store ofre 
for frihedens sag over hele kloden.

Jo, der har været uoverensstemmelser mellem Amerika og Europa. Og utvivlsomt vil det også komme til nye uoverensstemmelser mellem os i fremtiden. Men det globale medborgerskabs byrder vil fortsat knytte os til hinanden. Et skifte i lederskab i Washington vil ikke løfte byrden. I dette nye århundrede vil både amerikanere og europæere blive nødsaget til at gøre mere - ikke mindre. Partnerskab og samarbejde mellem nationerne er ikke et valg. Det er en vej, den eneste vej, til at beskytte vor fælles sikkerhed og til fremskridt for vor fælles menneskehed.

Dette er grunden til, at den største fare for os alle vil være, hvis vi tillader nye mure at skille os fra hinanden.

Murene mellem de gamle allierede på hver side af Atlanten kan ikke blive stående. Murene mellem de lande, der har mest, og dem, der har mindst, kan ikke blive stående. Murene mellem racer og stammer, indfødte og indvandrere, kristen, muslim og jøde kan ikke blive stående. Det er nu disse mure, vi må rive ned.

Vi ved, at de er faldet før. Efter århundreders strid har Europas folkeslag skabt en Union af løfter og velstand. På dette sted, ved fundamentet til en søjle, der blev opført for at markere sejr i en krig, mødes vi i aften i centrum af et fredens Europa. Ikke blot er mure faldet i Berlin, de er også faldet i Belfast, hvor prote- stanter og katolikker fandt en vej til at leve sammen. Og i Balkan, hvor vor atlantiske alliance sluttede krige og stillede brutale krigsforbrydere for retten. Og i Sydafrika, hvor et modigt folks kamp besejrede apartheid.

Så historien lærer os, at mure kan rives ned. Men opgaven er aldrig let. Et ægte partnerskab og ægte fremskridt kræver et konstant arbejde og vedholdende ofre, og kræver, at vi deles om byrderne i udvikling og diplomati, for fremskridt og fred. Dette forudsætter allierede, som vil lytte til hinanden, lære af hinanden og frem for alt: stole på hinanden.

Dette er grunden til, at Amerika ikke kan vende sig indad. Og til at Europa ej heller kan vende sig indad.

Tiden må nu være inde til, at vi kloden over bygger nye broer, der har samme styrke som den, der binder os sammen over Atlanten. Tiden må nu være inde til, at vi går sammen og ved stadigt samarbejde, stærke institutioner, fælles ofre og globalt engagement møder det 21 . århundredes udfordringer.

Det var en sådan ånd, som fik luftbroens flyvemaskiner til at komme til syne på himlen over vore hoveder og mennesker til at samles her, hvor vi står i dag. Og øjeblikket er nu kommet, hvor vore nationer - og alle nationer - igen må finde tilbage til denne ånd.

Dette er øjeblikket, hvor vi må besejre terroren og tørlægge den 
ekstremismens sump, der støtter den. Denne trussel er reel, og vi kan ikke unddrage os vort ansvar for at bekæmpe den. Når vi kunne oprette NATO for at tage konfrontationen med Sovjetunionen, kan vi sammen gå ind i et nyt og globalt partnerskab om at optrævle de netværk, som slog til i Madrid og Amman, i London og Bali, i Washington og New York.

Når vi kunne vinde idékampen imod kommunisterne, kan vi stå sammen med det overvældende flertal af muslimer, som forkaster den ekstremisme, der fører til had i stedet for håb.

Dette er øjeblikket, hvor vi må styrke vort fortsæt om at tilføje de terrorister, som truer vor sikkerhed i Afghanistan, et afgørende nederlag og gøre op med de smuglere, som sælger narko i vore gader.

Ingen hilser en krig velkommen. Jeg anerkender de enorme vanskeligheder i Afghanistan. Men mit land og jeres har en andel $i$ at se til, at NATOs første mission uden for Europas grænser bliver en succes. For Afghanistans folk og for vor fælles sikkerhed må denne opgave løses. Amerika kan ikke gøre dette alene. Det afghanske folk behøver vore tropper og jeres tropper, vor støtte og jeres støtte til at besejre Taleban og al-Qaeda, til at udvikle deres økonomi og til at hjælpe dem med at genopbygge deres nation. Der står for meget på spil for os til, at vi kan bakke ud nu.

\section{En verden uden atomvåben}

Dette er øjeblikket, hvor vi igen må besinde os på målet om en verden uden atomvåben. De to supermagter, som stod over for hinanden på hver side af muren i denne by, kom tæt på at ødelægge alt, vi har bygget og alt, hvad vi elsker. Nu da denne mur er væk, behøver vi ikke at stå passivt og se på den videre spredning af det dødbringende atom. Det er på tide, at alt atomart materiale, der i omløb, bliver sikret. Det på tide, at vi stopper spredningen af atomvåben og reducere arsenalerne fra en anden tid. Dette er øjeblikket til at begynde arbejdet for at søge fred i en verden uden atomvåben.

Dette er øjeblikket, hvor enhver nation i Europa må have chancen for at vælge sin egen morgendag fri fra gårsdagens skygger. I dette århundrede behøver vi en ny stærk Europæisk Union, der kan styrke dette kontinents sikkerhed og velstand og samtidig række hånden ud til andre lande. I dette århundrede - i denne by af alle byer - må vi forkaste fortidens koldkrigs-tankesæt og sætte os for at samarbejde med Rusland, når vi kan, at gå i brechen for vore værdier og at søge et partnerskab, der kan spænde ud over et helt kontinent.

Dette er øjeblikket, hvor vi må bygge på den velstand, som åbne markeder har skabt og deles mere ligeligt om dens goder. Handel har været en hjørnesten i vor vækst og i 
den globale udvikling. Men vi vil ikke blive i stand til at opretholde en vækst, hvis den kun tilgodeser de få og ikke de mange. Sammen må vi opbygge et handelssystem, der i sandhed belønner det arbejde, som skaber velstand, og som er kombineret med meningsfuld beskyttelse for vore befolkninger og vor planet. Dette er øjeblikket for en handel, der er fri og fair for alle.

\section{Vi må redde planeten}

Dette er øjeblikket, hvor vi må hjælpe til at bønhøre råbet om et nyt daggry i Mellemøsten. Mit land må stå sammen med jeres og Europa om at sende et direkte budskab til Iran, at det skal opgive sine nukleare ambitioner. Vi må støtte de libanesere, som har marcheret og blødt for demokrati og de israelere, som søger en sikker og varig fred. $\mathrm{Og}$ uanset fortidens uoverensstemmelser er dette øjeblikket, hvor verden bør støtte de millioner af irakere, som søger at genopbygge deres tilværelse, også når vi overdrager ansvaret til den irakiske regering og omsider bringer denne krig til afslutning.

Dette er øjeblikket, hvor vi må gå sammen om at redde denne planet. Lad os beslutte os til, at vi ikke vil efterlade en verden til vore børn, hvor oceanerne stiger, hungersnød breder sig, og grufulde storme ødelægger vore jorder.

Lad os beslutte os for, at alle natio- ner - herunder også min egen - vil handle med samme seriøse målrettethed, som jeres nation har gjort og reducere den $\mathrm{CO}_{2}$, vi sender ud i atmosfæren. Dette er øjeblikket til at stå sammen som én.

Og dette er øjeblikket, hvor vi må give håb til dem, som bliver ladt $\mathrm{i}$ stikken i en globaliseret verden. Vi må huske på, at Den Kolde Krig, som kom til verden i denne by, ikke var et slag om territorium eller rigdomme. For 60 år siden kastede de fly, der fløj over Berlin, ikke bomber. I stedet bragte de mad, kul og slik til taknemmelige børn. De vandt hjerter og sind, kærlighed og loyalitet og tillid - ikke blot hos indbyggerne i denne by, men hos alle, som hørte beretningen om, hvad de udrettede her.

$\mathrm{Nu}$ vil verden se til og huske på, hvad vi gør her - hvad vi stiller op med dette øjeblik. Vil vi række vore hænder ud til folkene i de glemte hjørner af denne verden, som higer efter en tilværelse med værdighed og muligheder, med sikkerhed og retfærdighed? Vil vi løfte barnet i Bangladesh ud af fattigdom, sikre husly for flygtningen i Tchad og fjerne AIDS'ens svøbe i vor tid?

Vil vi stå op for menneskerettigheder for dissidenten i Burma, bloggeren i Iran eller vælgeren i Zimbabwe? Vil vi honorere betydningen af ordene 'aldrig mere' i Darfur?

Vil vi indse, at der ikke findes noget mere magtfuldt eksempel end det, som hver af vore nationer kan 
sætte for verden? Vil vi forkaste tortur og stille os på retsprincippernes side?

Vil vi byde indvandrere fra andre lande velkomne og afholde os fra diskrimination imod dem, der ikke ligner os eller dyrker samme religion som vi og holde løftet om lighed og muligheder for alle vore medborgere?

Borgere i Berlin - borgere i verden - dette er vort øjeblik. Dette er vor tid.

\section{Vores fælles historie}

Jeg ved, at mit land ikke har nået fuldkommenhed. Til tider har vi kæmpet for at holde fast i løftet om frihed og lighed for alle vore landsmænd. Også vi har gjort os skyldige i fejltagelser, ligesom der har været tider, hvor Amerikas handlinger verden over ikke har levet op til vore bedste hensigter.

Men jeg ved også, hvor meget jeg elsker Amerika. Jeg ved, at i over to århundreder har vi stræbt - under store omkostninger og store ofre for at udforme et mere fuldkomment fællesskab og for, sammen med andre nationer, at finde frem til en mere håbefuld verden. Vores troskab gjaldt aldrig en bestemt stamme eller kongerige - ja, hvert et sprog tales i vort land, hver kultur har sit præg på vores, hvert et syns- punkt bliver udtrykt på vore offentlige pladser. Det, som altid har forenet os - det, som altid har drevet os frem som folk, og det, som også drev min far til Amerikas kyster - er et sæt af idealer, som appellerer til forhåbninger, alle mennesker deler: At vi kan live i frihed fra frygt og nød, at vi kan sige, hvad vi mener og mødes med hvem, vi vil og dyrke den gud, vi ønsker.

Det er de forhåbninger, som fik alle nationers skæbne til at blive én i denne by. Disse forhåbninger er større end noget, der kan splitte os. Det er på grund af disse forhåbninger, at luftbroen begyndte. Det er på grund af disse forhåbninger, at alle frie mennesker - overalt - blev borgere i Berlin. Det er for at forfølge disse forhåbninger, at en ny generation - vor generation - må sætte vores præg på historien.

Borgere i Berlin - og borgere i verden - af omfang er vor udfordring stor. Vejen frem vil blive lang. Men jeg er kommet her for at fortælle jer, at vi er arvtagere til en kamp for frihed. Vi er et folk af usandsynligt håb. Lad os bygge på vores fælles historie og gribe vor fælles skæbne og lad os igen engagere os i den ædle kamp for at bringe retfærdighed og fred til vor verden.

Oversat af Niels Ivar Larsen. 